(Paper No. 2995.)

\title{
"Strengthening the East Row and Upgang Viaducts on the Whitby and Loftus Railway.
}

By William Robertson Lidderdale Forrest, Assoc. M. Inst. C.E.

The Whitby and Loftus Railway connects the Whitby and Picton branch of the North Eastern Railway, and the Scarborough and Whitby Railway at Whitby, with the Cleveland branch of the North Eastern Railway at Loftus. In was constructed in the early seventies by the Whitby, Redear and Middlesbrough Union Railway Company; the late Mr. John Dixon of London acted as engineer for the viaducts.

The railway crosses several ravines, varying in width between 300 feet and 1,000 feet, over which it is carried by the Staithes Viaduct, having six spans of 60-foot Warren girders, and eleven spans of 30-foot plate girders; the Upgang Viaduct, having five spans of 60 -foot and one of 27-foot trellis girders; the Newholm Viaduct, having eleven spans of 30 -foot plate girders; the Sandsend Viaduct, having eight spans of 30 -foot plate girders; and the East Row Viaduct, having six spans of 60 -foot trellis girders and two spans of 30 -foot plate girders. These viaducts are all constructed for a single line of railway and are of the deck type. The main girders are spaced 7 feet apart from centre to centre, and are supported on piers composed of two tubular wrought-iron plate columns $\frac{5}{16}$ inch thick, varying in diameter between 2 feet 6 inches and 3 feet 6 inches, braced together and filled with concrete, and having cast-iron flanges standing on a foundation of concrete. The way-beams were originally carried on 5 -inch by $2 \frac{1}{2}$-inch by $\frac{7}{16}$-inch angle-iron cross girders.

The line was taken over by the North Nastern Railway Company in 1878, but before the Board of Trade would approve of it being: opened for passenger traffic, longitudinal bracing had to be added between the taller piers, outside wrought-iron wheel-guards had to be provided, and the cross girders strengthened by having 6 -inch by $2 \frac{1}{2}$-inch channel-bars riveted to the angle-irons. This work was carried out by the Company, and the line was finally opened on the 3rd December, 1883. 
The object of this Paper is to describe recent strengthening of the viaducts having trellis girders, viz., the Upgang Viaduct, which crosses a ravine a short distance north of Whitby at a height of 70 feet, and the East Row Viaduct, which crosses a portion of the seashore at about 35 feet above high water of spring tide, about $2 \frac{1}{2}$ miles north of Whitby. The main girders were 5 feet deep and had top and bottom booms composed of 9 -inch by $\frac{3}{8}$-inch plates, and two angle-irons 6 inches by 3 inches by $\frac{7}{16}$ inch. They were divided into eleven bays of 5 feet, with a short piece of plate-web at each end. The diagonals of the four end bays were composed of two flat bars spread 4 inches apart at the intersection of the bracing. The bars in the end bays measured 6 inches by $\frac{7}{16}$ inch, those in the second being 6 inches by $\frac{3}{8}$ inch, and those in the third and fourth 5 inches by $\frac{5}{16}$ inch. The bracing of the three centre bays was composed of 4-inch by 3 -inch by $\frac{5}{16}$-inch angle-irons. The struts were formed of flat bars, with distance-pieces placed about 15 inches apart. Many of these struts were found to have buckled considerably, Figs. 1, particularly those of the third bays, and two were completely broken through. The broken struts were temporarily secured with timber, $3 \frac{1}{2}$-inch by $3 \frac{1}{2}$-inch by $\frac{1}{2}$-inch angle-irons were

Fig. 1.

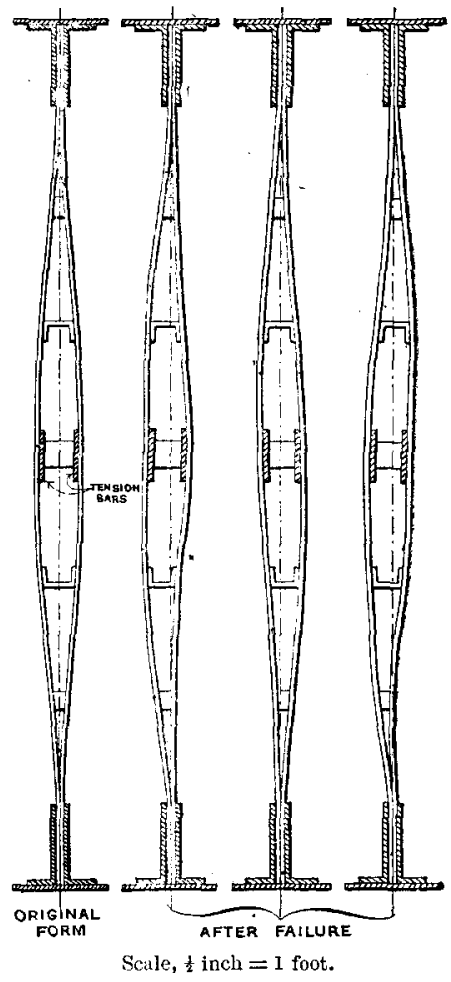

Buckled Struts on the East Row aNd UpGang ViadUCts. riveted on, and the work of strengthening the whole of the girders was then commenced.

Upgang Viaduct.-The girders of Upgang Viaduct were strengthened by attaching to the old flanges a new system of $\mathrm{N}$ bracing, sufficiently strong to do the whole work: 'I'he verticals were each composed of two T-irons, those of the four-end verticals being 6 inches by 4 inches by $\frac{5}{8}$ inch, and those of the three centre verticals being 6 inches by 3 inches by $\frac{1}{2}$ inch. The diagonals 
were composed of two flat bars varying between 8 inches by $\frac{5}{8}$ inch, and at the ends, 6 inches by $\frac{1}{2}$ inch, at the centre of the girder. In order to avoid interference with the traffic, or the cost of temporarily supporting the flooring from the ground, the old bracing was not interfered with, ard the new bracing was attached clear of it. The new vertical posts were therefore placed midway between the old posts, and, with the diagonals, were bent out on either side to clear the old work. The new bracing was attached to the old flanges by $\frac{7}{8}$-inch gusset-plates inserted between the angle-irons of the flanges. The rivet-holes were drilled to template $\frac{1}{8}$ inch less than the finished dimensions, and were subsequently rimered out to the full size. The new bracing-bars and T-bars were sent to the site, having the holes at one end $\frac{1}{8}$ inch less than the full size. The work was then bolted together in position, and the holes requiring it were rimered to the full size. As soon as each hole was finished, a turned bolt was inserted, and when all the holes of one span had been completed, the work of riveting was commenced. No rimering or riveting was allowed when a train was on the bridge. Sufficient scaffolding was hung from the ends of the cross-girders to enable work at two spans to be carried on at the same time. In carrying out the work, $47 \frac{1}{2}$ tons of iron were used, the total cost being $\$ 714$. The contract was entered into on the 6 th December, 1893, and the work was finished by the 30 th August, 1894.

East Row Viaduct.-At East Row Viaduct, owing to the extent of corrosion, and the generally bad condition of the trellis girders, it was decided to replace them by new steel girders of the $\mathrm{N}$ type of bracing, having vertical struts and inclined ties. The old trellis girders were 60 feet long and 5 feet deep, the ratio of depth to length being thus $1: 12$. The new girders are 7 feet $3 \frac{3}{4}$ inches from centre to centre of the booms, thus increasing the ratio to $1: 8$. They are divided into eight bays of 7 feet $3 \frac{3}{4}$ inches, the angle of inclination of the ties being $45^{\circ}$. The top boom is composed of two channel-bars placed back to back 9 inches apart, stiffened at intervals by 9 -inch by 3 -inch by $\frac{3}{8}$-inch channel-bars, additional sectional area where required being obtained by riveting plates to the top of the channel-bars. The bottom boom is composed of two flat bars placed 9 inches apart, and the area is increased where necessary by the addition of flat bars on the outside. Cross bracing is fixed between each pair of girders, which are 7 feet apart from centre to centre, at the first and third posts, and also over each pier. The cross girders are attached to 
the new main girders by flat plates fastened to angle-cleats on the crossgirders by turned bolts; and they are also riveted to the top boom of the new girders. In designing the girders 20 per cent. additional sectional area was allowed to cover increase in the weights of locomotives and reduction of area by corrosion.

A substantial timber staging, Figs. 2 , was constructed, from which the flooring of the viaduct was supported while the new girders were erected. It consisted of four trestles braced together in pairs, the

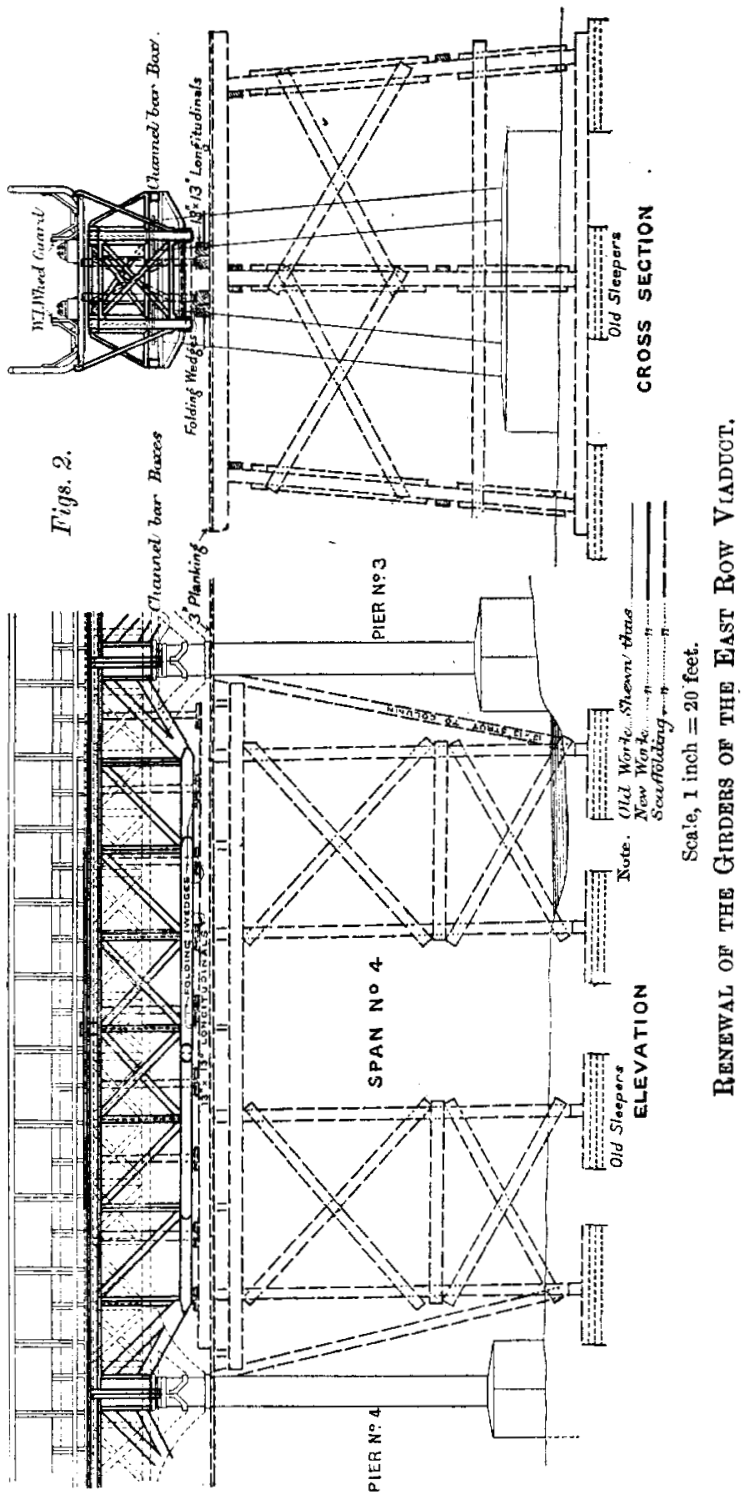
whole being connected longitudinally at the top with 13-inch by 61 -inch timbers spliced between the two pairs of trestles. The 
sills of the trestles were supported on piers 9 feet by 9 feet, formed of sleepers laid across one another on the sand of the beach. A platform of 3-inch planking was carried on the crown trees and by intermediate cross-beams resting on the longitudinal timbers. The same staging was used for each span, each pair of trestles being rolled out intact from under the viaduct, and placed in position where they were next required.

While the staging was being prepared, men were employed in cutting out rivets, and replacing them with service bolts, and generally in preparing the work so that there should be as little as possible to do on the Sunday on which the new girders were to be placed in position. After possession of the line was obtained, generally shortly after 9 o'clock on the Saturday night, the girders were lowered upon the staging, each on its respective side, and were placed in cradles. Meanwhile all the bolts connecting the old girders with the flooring and adjacent girders were taken out, and the rakers to the flooring, and the brackets at the tops of the columns were removed. After the girders had been lowered, the plate-layers disconnected the permanent way. The work of raising the flooring was then commenced by means of two 50-ton, two 40-ton, one 15-ton, and one 10-ton hydraulic jacks placed under the cross girders. As the flooring was raised, the folding wedges under the sleepers supporting the props to the cross girders were driven tight, this operation being repeated until the floor had been raised about 3 inches. When the flooring was raised the work of replacing the girders was commenced.

The crane-chains were fastened to the ends of the old girders on the north or sea side, and were tightened so as to ease the girder off its bearings. The girder was then swung out and placed on the bridge flooring. The old girder being out, the packingpieces between the new girders and the cross girders were bolted on to the underside of the cross girders. The chains were then fastened on to the new girder, and it was swung into position, the operation being repeated with the south girders. The girders being fixed, the pier-brackets were placed in position, the flooring was lowered on to the girders, and the cross bracing was fixed in position. All the work was then bolted up, and the permanent way was re-connected.

The longest and shortest time occupied in the erection of a pair of girders is shown in the Table on the following page.

The number of men employed continuously on the erection averaged thirty; these were augmented on Sundays, when the new girders were erected, by a gang of six men. Two 10-ton 


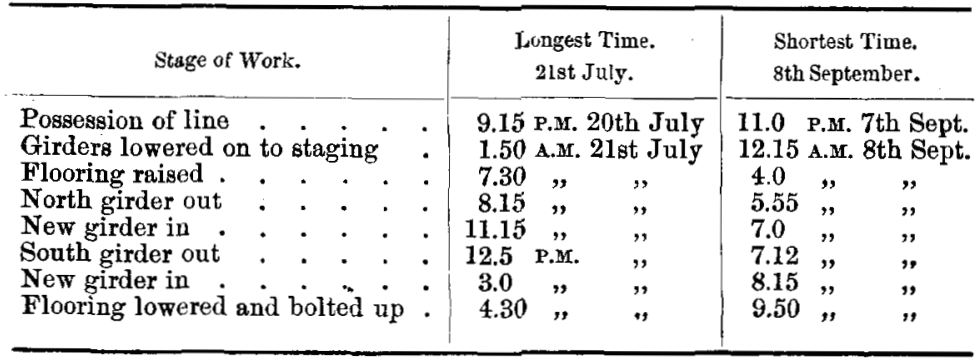

steam-cranes were used. The quantities and cost of the work were as follows :-

\begin{tabular}{|c|c|}
\hline $\begin{array}{l}\text { is pairs of girders with intermediate cross bracing } \\
\text { weighing } 101 \text { tons at } £ 10 \text { per ton }: \cdot \cdot \cdot\end{array}$ & $\begin{array}{cc}\stackrel{s}{*} & s \\
1,010 & 0\end{array}$ \\
\hline $\begin{array}{l}\text { on stays, \&c., weighing } 9 \text { tons } 13 \mathrm{cwt} . \\
0 d \text { per ton } \cdot . \\
\end{array}$ & 13015 \\
\hline rection, including seaffolding, six spans at $£ 220$ per span & 1,320 \\
\hline Sundries $\cdot \cdot \cdot \cdot \cdot \cdot \cdot \cdot \cdot \cdot \cdot \cdot \cdot \cdot \cdot \cdot \cdot \cdot \cdot \cdot$ & 10710 \\
\hline 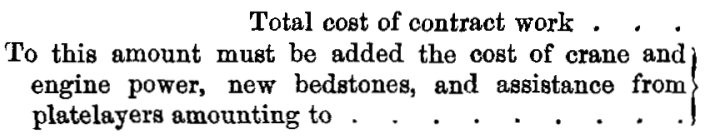 & 2,568 \\
\hline Total & \\
\hline
\end{tabular}

The contract was entered upon on May 9,1895 , and the work was finished by the 31st October, 1895, the contractors for this, as for the Upgang Viaduct also, being the Cleveland Bridge and Engineering Company of Darlington.

Shortly after the erection of the first pair of girders, a severe storm passed over the district, causing the stream under the fourth span of the viaduct to be flooded; and, owing to the obstruction of the scaffolding and the debris brought down by the flood, the waterway became blocked, and the stream diverted its course and cut out a channel under the fifth span 2 feet 6 inches deeper than the original channel, clearing away some of the sand for a dept's of about 2 feet 6 inches below the foundations of the fifth pier. As a temporary measure a dry wall of large stones was built in front of the concrete, Figs. 3, and as soon as possible this wall was grouted with eement mortar. Sheet piling was driven in front of the rubble wall and returned at each end into the bank. The main piles were driven 21 feet and the sheet piles 12 feet through the sand into blue ciay; 12 -inch by 6-inch walings were bolted to the top of the piles, the top of the walings 
being about 1 foot above the level of the sand in the river-bed. The sand behind the piles was excavated in short lengths to a depth of 18 inches below the toe of the rubble wall for a width of 4 feet in front and of 7 feet 6 inches at the ends; concrete was then deposited and a brick wall built in front of and against the rubble wall, the thickness averaging about 2 feet 6 inches. This brick wall was turned round the ends into the bank. The brickwork was built up to the level of the road under the sixth span, about 8 feet 6 inches above the top of the walings. A dwarf wall was built along the back joining the ends of the two

Figs. 3.

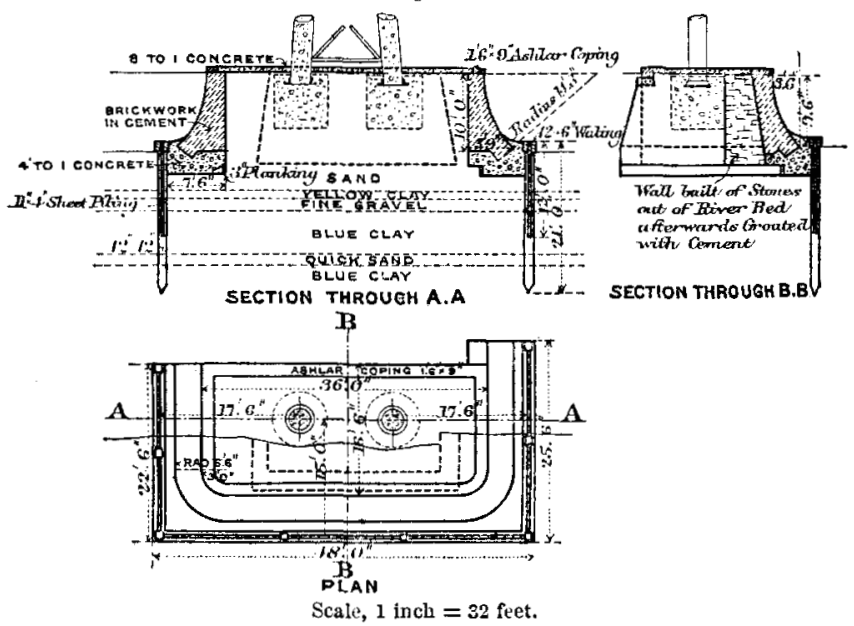

Retair of the foundations of Pier No. 5, East Row Viadoct.

end walls, and the enclosed space on the top was covered with a layer of concrete about 9 inches thick, the whole being finished off with an ashlar coping 18 inches by 9 inches. This work was carried out by the Company's staff.

The works were carried out under the supervision of the Railway Company's Engineer, Mr. W. J. Cudworth, M. Inst. C.E., under whom the Author was employed on the drawings and as Resident Engineer.

The Paper is accompanied by four tracings and nine photographs, from which the Figs. in the text have been prepared. 